\title{
The Aquila tower: a part of the Renaissance coastal defence system of Pučišća
}

\author{
Snježana Perojević ${ }^{a}$, Branislav Trifunović ${ }^{b}$ \\ ${ }^{a}$ Faculty of Civil Engineering, Architecture and Geodesy - University of Split, Split, Croatia, snjezana.perojevic@gradst.hr \\ ${ }^{\mathrm{b}}$ Kugla projekt d.o.o., Split, Croatia, kugla@hi.t-com.hr
}

\begin{abstract}
At the end of the fifteenth century the Ottoman Empire won the land at the middle of the eastern side of the Adriatic, between the town of Omiš and the Neretva River. Thus exposing the northern settlements of the island of Brač, which were under the Venetian Administration at the time, to immediate danger from the Turkish invasion. The settlement of Pučišća was particularly vulnerable. Therefore, the settlement was intensively fortified, and a series of thirteen individual small coastal towers was built, after which the entire settlement was named Castello Pucischia in 1600.

One of these towers -the Aquila tower- had a key role in defending Pučišća during the OttomanVenetian War, also known as the War of Cyprus (1570-1573). The Aquila tower was built at the beginning of the sixteenth century and today it is a well-preserved detached building situated on the Pučišca coast. Despite all the damage and transformations endured in the past, all the tower elements have been sufficiently preserved to reconstruct its original appearance, including the residential character of the overall interior: a stone wardrobe and a built-in stone basin (Cro. pilo), a fireplace, stairs, as well as those of a defensive character: mechanisms for lifting the drawbridge, loopholes, cannon openings, channels for extracting gunpowder smoke. The wooden beams' supports in the walls above the first floor have also been preserved, as well as the barrel vault over the ground floor and the groin vault over the second floor which are still intact even today. On the external of the tower, the original corbels of machicolations as well as the semi-circular cornice above the escarp are partially preserved.

By analysing the remains of the tower and by studying historical and bibliographic sources, a reconstruction of the original appearance of the Aquila tower has been made, both for the external and internal part, including transformations that took place over the time, since its construction to the present day. This has contributed to the knowledge of the typology of Renaissance coastal fortifications as well as to providing basis for potential renovation and reconstruction of the Aquila tower.
\end{abstract}

Keywords: Aquila tower, coastal fortifications, Renaissance, island of Brač.

\section{Introduction}

The building -the Aquila tower, though shaped as a common representative of its building type and period- has historical significance and perseverance level making it a valuable monument of the Renaissance fortification system on the eastern coast of the Adriatic Sea.
The Aquila tower is a free-standing detached square plan building situated in the southwestern corner of Pučišća bay on the island of Brač (Fig. 1). Southern and eastern facades are facing the sea while the other two facades are facing the neighbouring buildings separated from it by pedestrian-only streets. 
It was one of 13 towers raised in the same period in Pučišća (Fig. 2) after which the bay was named "La Valle delle Torri" (Vrandečić, 2016).

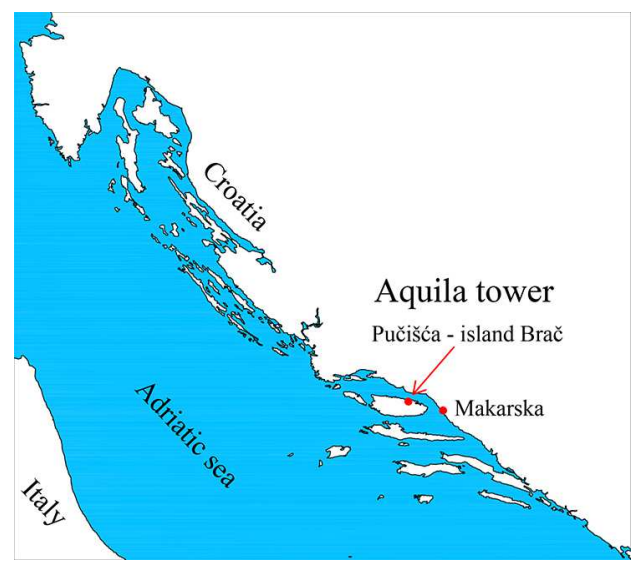

Fig. 1. Location of the Aquila tower (authors, 2019).

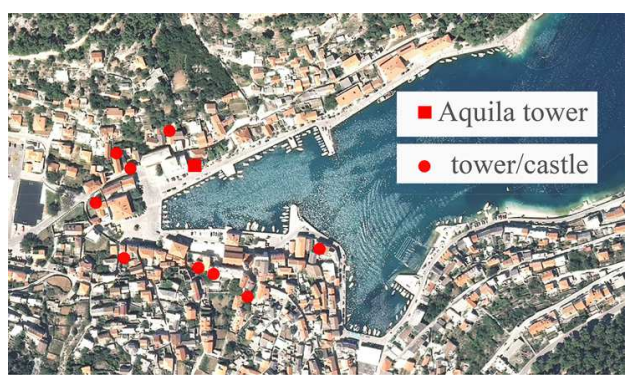

Fig. 2. Pučišća bay with marked towers and castles (authors, 2019).

The location of the tower and its characteristic appearance have been deeply imprinted on the perception of Pučišća and the tower has become a key point of the settlement (Fig. 3) earning thus its position as a symbol of Pučišća on its oldest coat of arms.

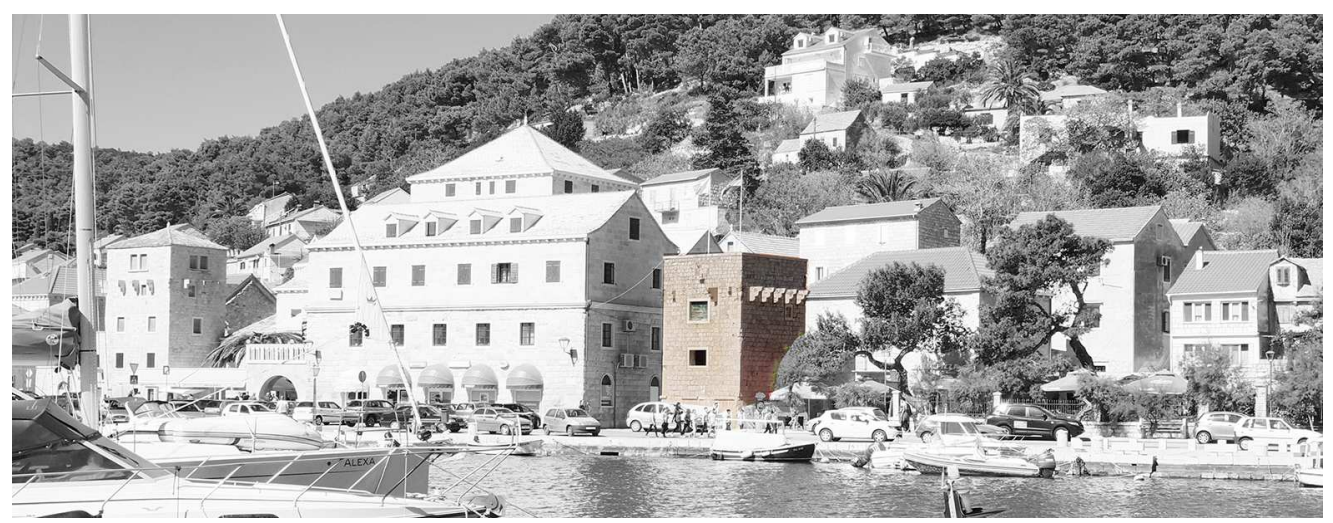

Fig. 3. A view of Pučišća with the prominent Aquila tower (authors, 2019).

Changes the building facades and its interior underwent through its long existence had no significant influence on its original appearance or value. The additionally added parts were removed in the meantime, thus leaving its original appearance (of a detached building) prominent in the area.

Masonry wall and all the other tower's original parts were sufficiently well-preserved enabling reconstruction of its original appearance using an architectural survey (Fig. 4, 5 and 6) captured to the most minute detail (done by a 3D laser scanner and a hand measuring) ${ }^{1}$.

\section{Historical and spatial context}

Settlements on the eastern coast of the Adriatic Sea were under constant threat from pirates and robbers, coming in the first place by sea, but in some cases by land as well. The necessity to have a fortified building acting both as a watchtower and a place for the residents to hide from robbers and store different goods until the danger passed led to the typology of coastal towers which were built on the entire Mediterranean according to the similar model. 


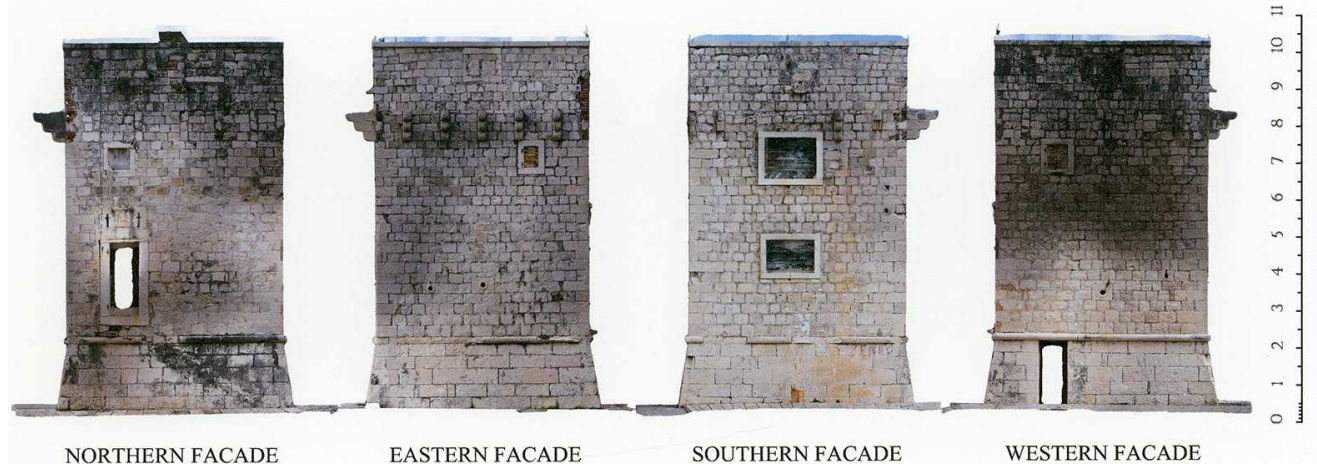

Fig. 4. Architectural survey of the Aquila tower facades obtained by a 3D laser scanner (Geographica d.o.o., 2018).
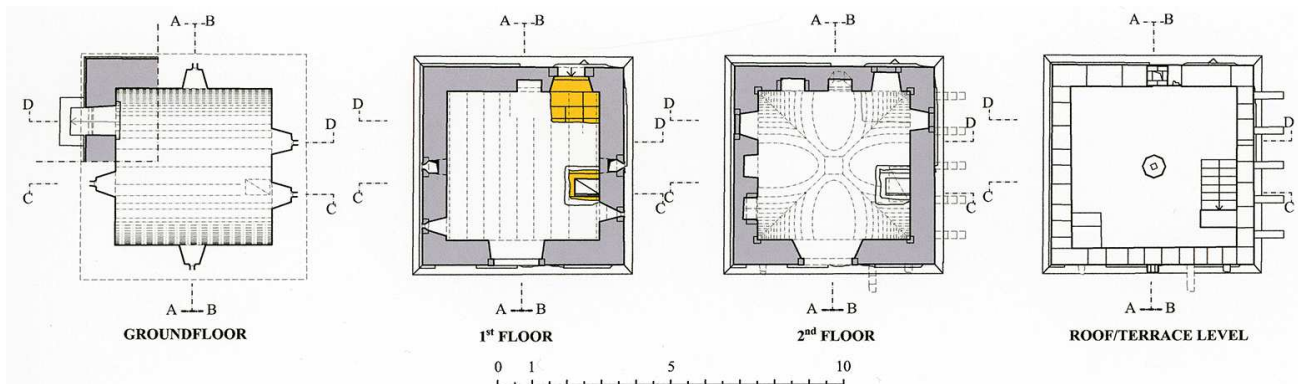

Fig. 5. Architectural survey of the Aquila tower plan (authors, 2018).

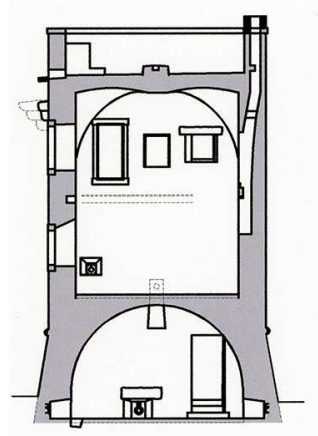

SECTION A-A

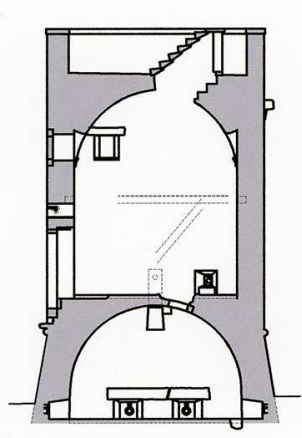

SECTION B-B

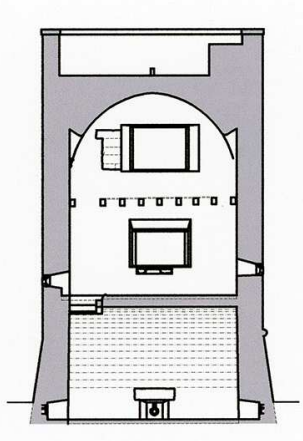

SECTION C-C

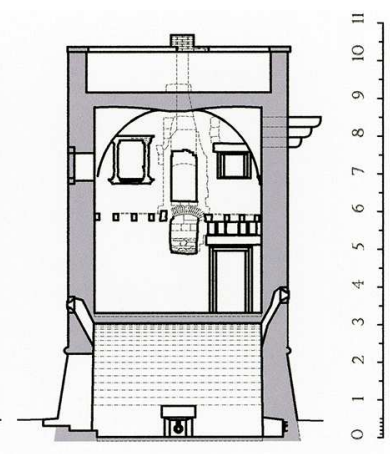

SECTION D-D

Fig. 6. Architectural survey of the Aquila tower cross-sections (authors, 2018).

Once the Venetians conquered the Dalmatian coastal settlements in 1444, ended the threat of pirate attacks, thus enabling people to move from the island's interior to its coast and inhabit Pučišća. However, this area soon became exposed to a danger from the Ottoman attacks. In 1463 Mehmed II conquered a wider hinterland of Dalmatia including Bosnia, the Neretva river and the Upper coastal regions while the Mak- arska (see Fig. 1) coastal region was conquered by the Ottomans in 1499. Pučišća became a border settlement and started fortifying its area by building thirteen defensive positions (towers), each soon surrounded by a wall including warehouse in order to preserve property, necessities, food, tools... In 1600, due to its significance, the entire settlement ceased to be called a village or 
bay and it was named "castello Pucischia" (Vrandečić, 2016).

\subsection{Construction period of the Aquila tower}

The tower was named after the Aquilas, a family from Pražnica who built it. The family name Aquila was mentioned in the first year of keeping the church register books: 1594 (Jutronić, 1950; Vrsalović, 1968). The exact time of the Aquila tower construction is unknown since the documents lack this information, but it can be determined from the tower's remains.

The relief of the well-preserved coat of arms of the Aquila family (Fig. 7), depicting a fight between an eagle (aquila) with wide wings and a snake, is placed above main entrance.

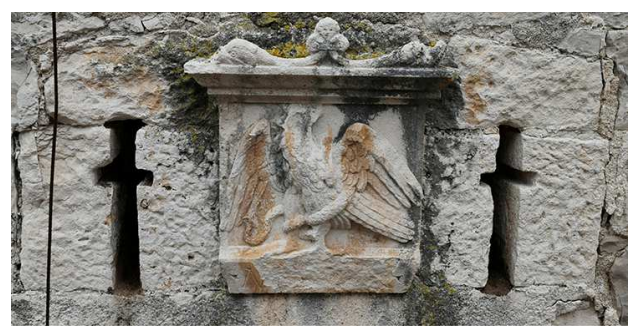

Fig. 7. Coat of arms of the Aquila family above main entrance (authors, 2019).

The year of construction was carved in the lower part of the relief in Renaissance Roman square capitals (Fig. 8). The inscription reads the first letter $\mathrm{M}$, a trace of the second letter $\mathrm{D}$, and a trace of the last letter that can only be an X due to remaining angled line. The size and shape of the letters indicate it could only be 4 letters, as in this period thousands and hundreds in dates were punctuated (as on Nikola Aquila's gravestone).

The tower was raised by Mate Aquila after construction of the first tower by Ciprian Žuvetić in 1467 (Ciccarelli, 1821), and the Aquila tower was already built according to a text dating from 1571 (PPA $^{2}$ ). The only years between 1467 and 1571 ending in $X$ and consisting of four letters were $\cdot \mathrm{M} \cdot \mathrm{D} \cdot \mathrm{IX} \cdot, \cdot \mathrm{M} \cdot \mathrm{D} \cdot \mathrm{XX} \cdot$ and $\cdot \mathrm{M} \cdot \mathrm{D} \cdot \mathrm{LX} \cdot$ i.e. 1509,1520 and 1560 . Mate Aquila was never mentioned in the later sources. Since the tomb of his successor Nikola is dating already in
1524 , so it can be assumed that the tower was built in 1509 .

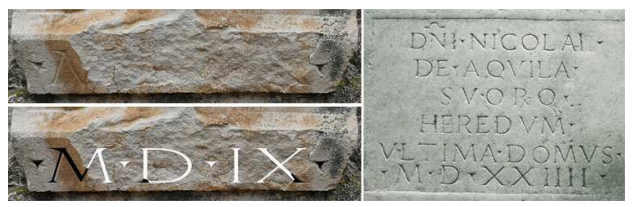

Fig. 8. (left) Details on the coat of arms with the carved year of construction (authors) and (right) a detail from Nikola Aquila's gravestone inscription (photo archive of the Split Department for Conservation).

\subsection{Role of the Aquila tower in the defence of Pučišća}

The Ottoman attack on Pučišća, as described in the literature (Ciccarelli, 1821) and archival documents (the event was described in detail by Nikola Aquila, son of the tower captain Juraj Aquila in 1603 - PPA), which was significant for the history of Pučišća as it put into operation the defence system of the settlement, especially the Aquila tower, took place during the OttomanVenetian War, also known as the War of Cyprus (1570-1573). The description vividly testifies to the dramatic attack and insecurity of life by inhabitants of the coastal settlements, but also to the significance that the modest structures, such as the Aquila tower, had for their defence. The description shows that these structures were also used for storing various goods.

On 13 June 1571, 1000 Ottoman soldiers attacked Pučišća from the sea. Women, children, the elderly and the weak withdrew to the fields outside the settlement and the defenders locked themselves inside the towers, defending themselves and causing great losses to the Ottoman invaders. The Ottomans, before being expelled, robbed and set fire to many houses. They attacked the Aquila tower on three different attempts, set fire to the gunpowder magazine and warehouse, and wounded the captain. Four months later, the Battle of Lepanto took place, eliminating the Ottoman danger from the sea, however the occasional danger of robbery by the Uskoks still remained. 


\subsection{Timeline of the Aquila tower transfor- mation}

As it can be seen from the Austrian land register (Fig. 9), in 1833 the tower was part of a fenced building complex described under entry number 346 and including the following units: twostorey dwelling house, warehouse, ruin referring to the tower itself, yard, cistern and fish pond.

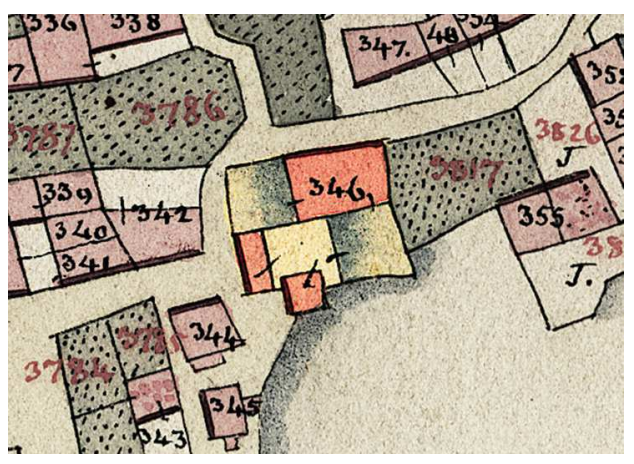

Fig. 9. An excerpt detail from the Austrian land register plan dating from $1833\left(\mathrm{DAS}^{3}\right)$.

The fenced yard was also mentioned during the siege of the tower in 1571 . However, it can be assumed from the position of the cannon openings on the ground-floor casemates (casamata) near the sea level that the tower was originally a free-standing structure, built on the cliffs and surrounded by the sea (Kovačić, 2010). The Austrian land register entry also shows that the tower was still partly in the sea. In the nineteenth century a new coastline was formed due to an embankment that moved the sea away from the tower and raised the terrain.

Recently, alterations have been made to the tower facades: two large windows were added on the southern facade and the door on the ground floor of the western facade. A part of machicolation corbels was torn off, the cordon cornice was damaged for about $50 \%$ of its length, and the roof floor was transformed into a flat terrace with a small staircase that protects the preserved original exit from the lower level of the tower.

\section{Description of the original appearance}

The Aquila tower was a typical coastal tower (torre costiere) from the period of fortification transition from the end of the fifeteenth and the beginning of the sixteenth century. It was built on a cliff with cannon openings on all four sides and its protruding position in the Pučišća harbour was confirmed by two cannon openings on the side facing the bay.

\subsection{Entrance}

The only entrance to the tower was from the northern side on the first floor (which had a residential function) and was accessed via a drawbridge. The bridge has not been preserved, but on both sides of the aforementioned Aquila family coat of arms, positioned above the entrance, cruciform loopholes used for mechanism for lifting the drawbridge have been preserved. The horizontal part of the cruciform loopholes were used for inserting a block and tackle system which remains have been preserved for both openings (Fig. 10). The block and tackle system consisted of an iron shaft inserted into a bronze square $(6,5 \times 6,5 \times 3,5 \mathrm{~cm})$ which carried a wooden pulley with a rope slot. A rope up to 30 $\mathrm{mm}$ in diameter was used for lifting the bridge and no lifting mechanism was required as the bridge was quite light.

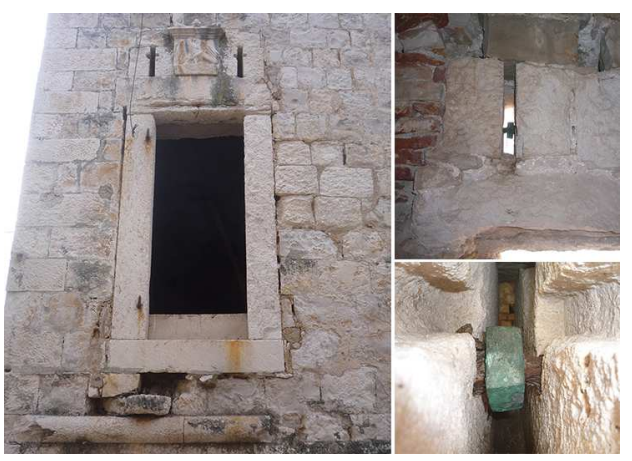

Fig. 10. Entrance on the first floor with the drawbridge lifting system remains (authors, 2019).

\subsection{Ground floor - casemate}

The ground floor is vaulted and atypical for this type of building because it functioned as an artillery chamber rather than a water tank as in most other towers of similar type. It was only accessed from the upper level by a ladder through an opening in the vault. For the extraction of gunpowder 
smoke, two ventilation channels were made in the thickness of the wall with an outlet on the outside of the tower (Fig. 11).

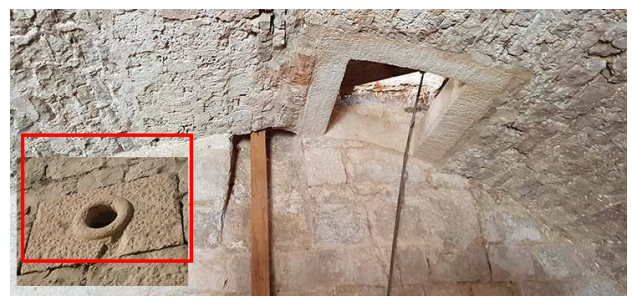

Fig. 11. The ground floor vault with the opening from the upper floor and ventilation channel with its outside outlet (authors, 2019).

The openings for light artillery on the ground floor were about $30 \mathrm{~cm}$ in height from the floor and about $12 \mathrm{~cm}$ in diameter, which indicates that they were small in calibre, and not visible from the outside today. Considering the annual sea level rise since the time of construction, it can be assumed that the original ground floor was approximately $60 \mathrm{~cm}$ above the sea level (about $10 \mathrm{~cm}$ today), and accordingly to the axis of cannons at about $90 \mathrm{~cm}$ from the sea level at the time.

The base of the tower was made of a steep escarp 1:6 $\left(81^{\circ}\right)$ ending in a cordon cornice at the transition to the vertical part of the masonry.

\subsection{Rooms on the first and second floors}

Above the ground floor is a unique space divided by wooden beams measuring $12 \times 17 \mathrm{~cm}$ at a distance of approximately $50 \mathrm{~cm}$ (according to the remains of the beams' supports) and $2,5 \mathrm{~cm}$ wooden boards. The first floor was tiled with partly preserved regular stone tiles. On the second floor, there was one window on each facade from the time the tower was built, offset from the central axis. Today, these windows are walled up on the outside as well as the one on the south from the inside. All four walls had approximately $20 \mathrm{~cm}$ thick stone lintel that went through the entire thickness of the wall. On the east and west wall of the first floor there was one loophole per wall, with a circular opening of approximately $12 \mathrm{~cm}$ in diameter, and a vertical peephole was positioned vertically above the openings as in casemates (Fig. 12).

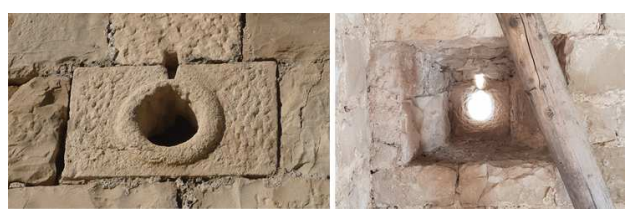

Fig. 12. Loophole - from the outside (left) and from the inside (right) (authors, 2019).

The interior was plastered (the remains of the plaster have been preserved on the sides of the loophole), but there are no traces of plaster on the tuff vault. The tower suffered at least one major fire so that all the stone parts of the interior, not covered with plaster, were permanently damaged. Recent architectural survey has managed to document the elements that are decaying daily due to moisture and salt.

On the first floor of the tower, besides the entrance and two loopholes, there is a niche in the northern wall, which was probably an ash dump of the fireplace because it extends into the fireplace opening, ending on the upper floor. The wooden beams' support structure has also been preserved. The walls on the inside of the second floor, besides the windows niches, have other interior elements installed. The remains of a Renaissance built-in stone basin (pilo) and the fireplace niche have been preserved (Fig. 13).

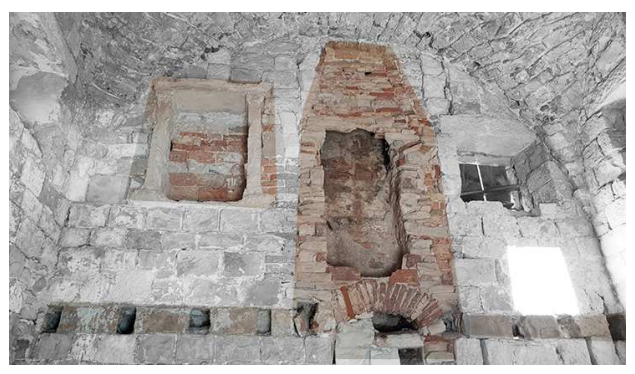

Fig. 13. Visible holes for the beams' support structure between the first and second floor, stone sink and fireplace (authors, 2019).

There is a stone cabinet with grooves for shelves (Fig. 14) and a niche without the stone frame in the western wall. 


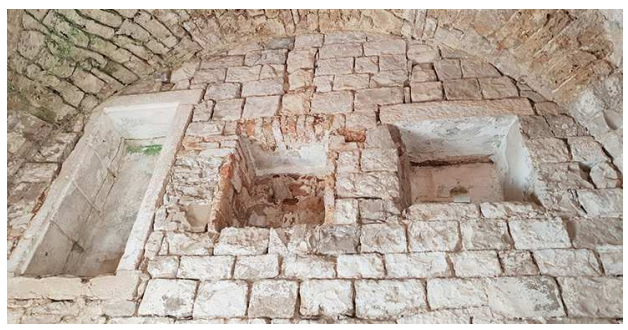

Fig. 14. Remains of the stone cabinet in the western wall (authors, 2019).

The two-storey space is covered with a crossbarrel tuff vault (Fig. 15) supporting the roof terrace. The vault had small stone corbels on the foot of the arch, two of which were preserved and suffered only minor damages. The exit leading to the roof level over a few stone steps has also been preserved (see section B-B, Fig. 6).

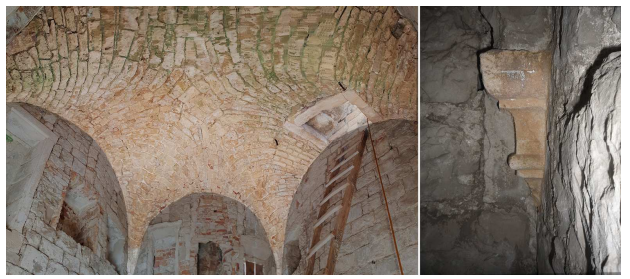

Fig. 15. Panoramic view of the cross vault with an opening for access to the roof-level and the preserved stone corbel (authors, 2019).

The first and second floors as well as the roof terrace were connected with a wooden staircase, which traces can still be seen on the eastern wall.

\subsection{The Aquila tower exterior}

It is assumed that the structure, in accordance with its typology, was covered with a four-sided roof (Kovačić, 2010) supported by the walled part of battlements. The tower edges were lined with machicolation on triple-shaped corbels which have been entirely preserved on the eastern side and they were the only ones at regular intervals, unlike those on the other facades. Therefore, it can be assumed that the machicolation wall was not supported by arches but by straight stone beams (as in the case of the Cerineo castle - island Brač: Fig. 16).

A double wall plate was laid over the battlement in order to take over horizontal forces and to wedge the rafters of the eaves. A stone tip (fini$a l)$ was placed on the top of the roof.

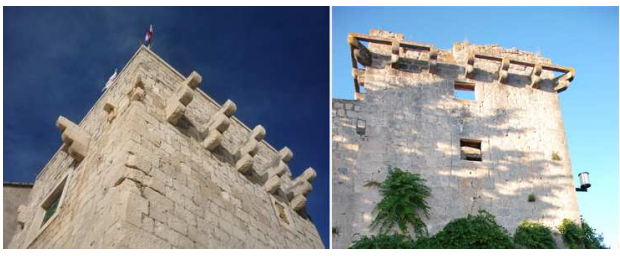

Fig. 16. (left) Machicolation corbels of the Aquila tower and (right) the Cerineo castle. ${ }^{4}$

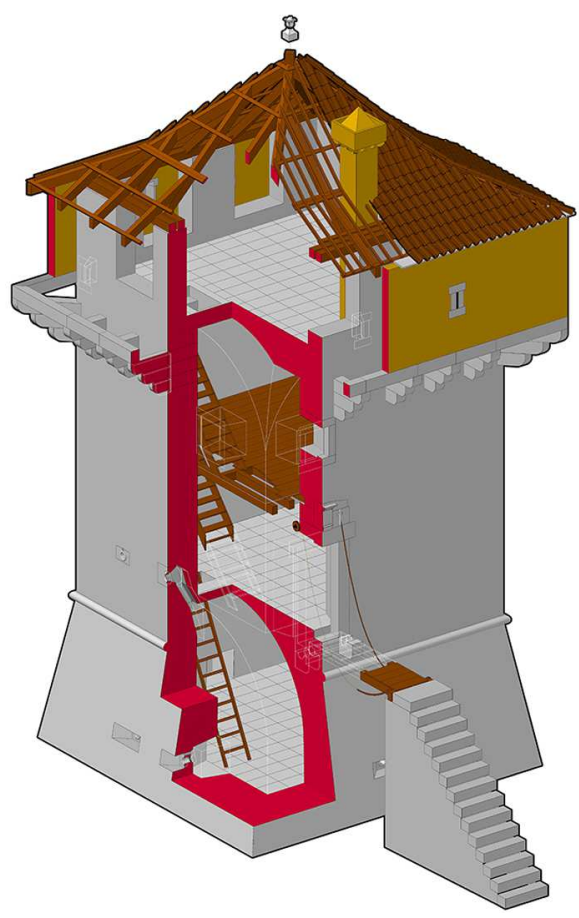

Fig. 17. Reconstruction of the original appearance of Aquila tower (authors).

\section{Conclusions}

The aim of the research was to accurately reconstruct the original appearance of all parts of the Aquila tower and to compare it to other towers (Fig. 185) from the same historical and geographical background, and to draw conclusions regarding the typology characteristics, similarities and peculiarities, summarizing the most significant ones. 


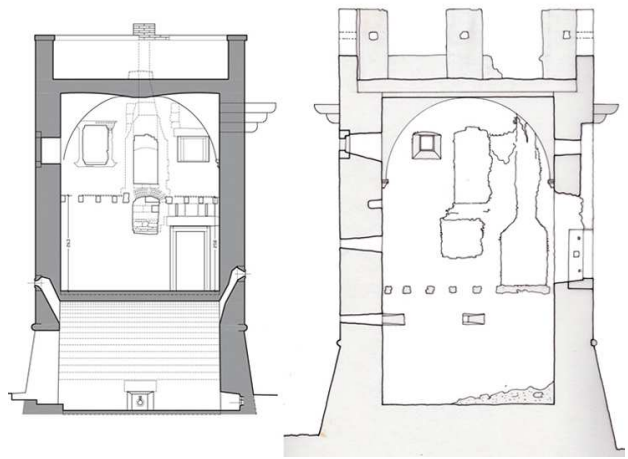

Fig. 18. Comparison of the Aquila tower cross-section (authors) to the Kaštel tower from Olib cross-section $\left(\mathrm{ZDC}^{6}\right)$ in the same ratio.

The Aquila tower vs the Kaštel tower from Olib: - exterior square plan 5,8 x 5,8 m (measured above the cordon cornice) vs $7 \times 7 \mathrm{~m}$ (wall thickness $0,7 \mathrm{~m}$ vs $1,2 \mathrm{~m}$ ) with the escarp on the ground floor level with cordon cornice ; tower height $=$ ground floor +2 floors $;$ the overall height (from the floor level of the ground floor to the floor level of the terrace $=9,2 \mathrm{~m}$ vs $9 \mathrm{~m}$; entrance to the tower on the first floor level, secured by a drawbridge ; cross barrel vault above the last floor, with corbels on the foot of the arch; small (observation) windows on the second floor, under the machicolation corbels on all facades.

\section{Notes}

${ }^{1}$ Architectural survey of the present condition authors and Geographica d.o.o. (2017-2018).

${ }^{2}$ PPA - Župni arhiv Pučišća (Eng. Pučišća Parish Archive). Documenti come $i$ Turchi assalirono Pucischie nella guerra di Cipro del 1571-; e gli Uscocchi di Segna nel 1586-, i quali nel 1614-uccisero in Pago Antonio Boccanich Capitanio Pucischiano

${ }^{3}$ DAS - Državni arhiv Split, Arhiv mapa za Istru i Dalmaciju (Eng. National Archives in Split, Map Archive for Istria and Dalmatia).

4 https://commons.wikimedia.org/w/index.php? curid=11126626 (26 October 2019).

${ }^{5}$ Given the limited format of this paper, some of the buildings used for comparisons and conclusions are not listed in the text - Vitturi/Paittoni tower in Trogir, Divinić house in Šibenik, Buća tower in Budva, Arboretum in Trsteno, Majić tower in Sebišina near Grude.

${ }^{6}$ ZDC - Konzervatorski odjel u Zadru (Eng. Zadar Department for Conservation).

\section{Bibliography}

Ciccarelli, A. (1821). Historički prikaz Pučišća, Reprint, Beograd, Fakultet primenjenih umetnosti et Bol, Zlatni rat, 1981.

Jutronić, A. (1950) "Naselja i porijeklo stanovništva na otoku Braču”, in Boranić, D.; Rubić, I. ed., Zbornik za narodni život i običaje, knj. 34, JAZU, Zagreb.

Kovačić, V. (2010). "Renesansne kule u Pučišćima na otoku Braču”, Klesarstvo i graditeljstvo, XXI, 1-2, pp. 49-67.

Vrandečić, J. (2016) "Povijest župe Pučišća”, in Vrandečić, J. ed., Spomenica župe sv. Jeronima Pučišća: povodom 450 godina utemeljenja (1566.-2016.), Župa sv. Jeronima, Pučišća, pp. 21-132.

Vrsalović, D. (1968). "Povijest otoka Brača”, Brački zbornik, 6, Supetar, pp. 391-446. 